\title{
Effect of Physical Activity on Prevalence of Risk for Obesity and Diabetes in School going Children and Adolescents
}

\author{
Manju Dewan
}

\begin{abstract}
Aim: The purpose of this study was to estimate the effect of physical activity on prevalence of risk for obesity and diabetes. Method: 2048 children had undergone questionnaire and dietary survey and health examination. Out of these, 1017 were from urban population and 1031 from rural population Children and adolescent aged 10-19 years were selected randomly for questioning regarding the different aspects of epidemiology and their health examination was done. Results: In the total population (2048), 35.21\% children were performing > 60 minutes physical activities. Diabetic children are more in the category performing $<60$ minutes of physical work. Boys were more physically active than girls. Overweight children were more in those performing $<60$ minutes activity. When the physical activity of rural and urban children is compared, urban children were inclined towards more sedentary behavior than rural children. Obese diabetic children were more in physically inactive category. Diabetic children were less physically active than normal ones. These findings indicated that promotion of physical activity is an important factor to prevent obesity and its related disorders. Subjects who were having impaired glucose levels were totally unaware of the diagnosis at the time of examination and physical inactive. Conclusion: Children can prevent the development of obesity and type -2 diabetes by increasing their level of physical activity. Childhood obesity can be prevented by living actively, eating in healthful ways and creating a nurturing environment.
\end{abstract}

\author{
Manju Dewan \\ Assistant Professor \\ PG Department of Zoology \\ DAV College, Sector 10, Chandigarh, India \\ E-mail: manjudewan72@gmail.com
}

Key Words: Physical activity, Eating behavior, Children, Obesity, Overweight, Type 2 diabetes

DOI: $10.18376 / j e s p / 2017 / v 13 / \mathbf{i} 2 / 111282$

\section{Introduction}

Overweight and obesity are one of the most important public health problems, which are being escalated as global epidemic (WHO,2014). Over-nutrition predisposes children to insulin resistance, metabolic syndrome, and type- 2 diabetes mellitus. Increasing prevalence of obesity and insulin resistance has been reported in Asian Indian adolescents (Guo et al, 2000). Obesity is not confined to adults but also found among the children and adolescents in the developed countries during the past two decades as well as similar trends are being observed even in the developing world,(Pouliot et al,1994, Martorell et al,2000 and Popkin, 2001). Behaviors influence obesity like eating high-calorie, low-nutrient foods, consuming soft drinks, physical inactivity and sedentary activities such as watching television, computer use and irregular sleeping habits. 
Children who have obesity are more likely to have obesity related disorders like hiigh blood pressure, high cholesterol, increased risk of impaired glucose tolerance, insulin resistance and type 2 diabetes, breathing problems, joint problems etc. (Mohanan et al, 2014, Pollock, 2016, Africa et al, 2016 Bacha and Gidding, 2016). If children have obesity, their obesity and disease risk factors in adulthood are likely to be more severe (Bass and Eneli, 2015). Childhood obesity is also related to psychological problems such as anxiety and depression (Beck, 2016). Childhood obesity is one of the most serious public health challenges of the $21^{\text {st }}$ century. One of the factors that is most significantly linked to obesity is physical inactivity. Decrease in physical activity among all age groups has heavily contributed to rising rates of obesity. Each additional hour of television watching per day increase the prevalence of obesity by $2 \%$. Television viewing among young children and adolescents has increased dramatically in recent years (Anderson and Butcher, 2006 and Kapil and Bhadhoria, 2014). Early recognition of obesity is important; it is possible by routine assessments of activity patterns in children. This study has shown that the increased amount of time spent in sedentary activities has decreased the amount of time spent in physical activity that leads to obesity and its related disorders.

\section{Materials and Methods}

2048 children had undergone questionnaire and dietary survey and health examination. Out of these, 1017 were from urban population and 1031 from rural population Children and adolescent aged 10-19 years were selected randomly for questioning regarding the different aspects of epidemiology and their health examination was done. The permission from parents of the children, undergoing examination and questionnaire survey was also taken on the self-designed consent form. The Centers for Disease Control and Prevention (CDC) suggests two levels of concern for children based on the BMI-for-age charts.

At the 85th percentile and above, children are "at risk for overweight". At the 95th percentile or above, they are "overweight". The cutoff for underweight of less than the 5th percentile is based on recommendations by the World Health Organization Expert Committee on Physical Status 1998.

Fasting blood sugar test was perfomed. The diagnostic criteria for diabetes mellitus have been modified from those previously recommended by WHO (1985). The revised criteria for the diagnosis of diabetes is used which is as follows:

Categories of Fasting plasma glucose (FPG) values are as follows:

$\mathrm{FPG}<110 \mathrm{mg} / \mathrm{dl}(6.1 \mathrm{mmol} / \mathrm{l})=$ normal fasting glucose;

$>\quad$ FPG $110(6.1 \mathrm{mmol} / \mathrm{l})$ and $<126 \mathrm{mg} / \mathrm{dl}(7.0 \mathrm{mmol} / \mathrm{l})=$ IFG (Impaired Fasting Glucose)/Prediabetes.

$>\quad \mathrm{FPG} \geq 126 \mathrm{mg} / \mathrm{dl}(7.0 \mathrm{mmol} / \mathrm{l})=$ diabetes

(Report of the Expert Committee on the Diagnosis and Classification of Diabetes Mellitus (2003)

\section{Results and Discussion}

Physical activity plays an independent role in protection against obesity and diabetes. In the total population (2048), 35.21\% children were performing > 60 minutes physical activities (Table 1, Graph 1,2 \&3). Diabetic children are more in performing $<60$ minutes physical work category. Boys were more physically active than girls. Overweight children were more in those performing <60 minutes activity. When the physical activity of rural and urban children is compared, urban children were found to have more sedentary behavior than rural children.Diabetes seems to affect groups that are subject to rapid changes in their way of life described as 'Westernization'. Similarly, in the present study, diabetic children were less physically active than normal ones. These findings indicated that promotion of 
physical activity may be important in the prevention of diabetes mellitus. The purpose of this study was to estimate the association between physical activity and presence of risk for diabetes. Subjects who were having impaired glucose levels were unaware at the time of diagnosis and physically inactive. On examination of the data regarding their habits, it is found that all such subjects were not performing any physical activity or exercise which indicates fully unawareness in children about their health. Thus, it is very clear that the physical exercise has got a profound affect on this disease. Rural urban shifts and migration are usually accompanied by change in levels of physical activity, almost invariably to a more sedentary pattern.

Table 1: Level of physical activity per day and its relationship with obesity and diabetes

\begin{tabular}{|c|c|c|c|c|c|c|}
\hline \multirow[t]{2}{*}{ Group/Sub Group } & \multicolumn{2}{|c|}{$<60 \mathrm{~min}$} & \multicolumn{2}{|c|}{$=60 \mathrm{~min}$} & \multicolumn{2}{|c|}{$>60 \mathrm{~min}$} \\
\hline & $\mathbf{N}$ & $\%$ & $\mathbf{N}$ & $\%$ & $\mathbf{N}$ & $\%$ \\
\hline \multicolumn{7}{|l|}{ Area } \\
\hline 1.Urban & 273 & 26.84 & 290 & 28.52 & 454 & 44.64 \\
\hline \multirow[t]{2}{*}{ 2.Rural } & 579 & 56.16 & 185 & 17.94 & 267 & 25.90 \\
\hline & \multicolumn{6}{|c|}{$\begin{array}{r}\text { Chi^}^{\wedge} 2=181.53 * *(d f: 2) \\
\text { C }=0.29\end{array}$} \\
\hline \multicolumn{7}{|l|}{ Gender } \\
\hline Male & 532 & 37.49 & 325 & 22.90 & 562 & 39.61 \\
\hline \multirow[t]{2}{*}{ Female } & 320 & 50.87 & 150 & 23.85 & 159 & 25.28 \\
\hline & \multicolumn{6}{|c|}{$\begin{array}{r}\mathrm{Chi}^{\wedge} 2=44.34 * *(\mathrm{df}: 2) \\
\mathrm{C}=0.15\end{array}$} \\
\hline \multicolumn{7}{|l|}{ FBG Categories } \\
\hline$<110$ & 833 & 41.80 & 460 & 23.08 & 700 & 35.12 \\
\hline $110-126$ & 9 & 28.12 & 11 & 34.38 & 12 & 37.50 \\
\hline.$>=126$ & 10 & 43.48 & 4 & 17.39 & 9 & 39.13 \\
\hline & \multicolumn{6}{|c|}{$\begin{array}{r}\text { Chi^}^{\wedge} 2=3.66(d f: 4) \\
\text { C }=0.04\end{array}$} \\
\hline \multicolumn{7}{|l|}{ Percentile Based } \\
\hline Under Wt. & 234 & 46.06 & 102 & 20.08 & 172 & 33.86 \\
\hline Healthy Wt. & 526 & 39.76 & 321 & 24.26 & 476 & 35.98 \\
\hline At Risk & 55 & 43.31 & 26 & 20.47 & 46 & 36.22 \\
\hline Over Wt & 37 & 41.11 & 26 & 28.89 & 27 & 30.00 \\
\hline & \multicolumn{6}{|c|}{$\begin{array}{r}\mathrm{Chi}^{\wedge} 2=9.26(\mathrm{df}: 6) \\
\text { C }=0.07\end{array}$} \\
\hline All Data & 852 & 41.60 & 475 & 23.19 & 721 & 35.21 \\
\hline
\end{tabular}


Journal of Exercise Science \& Physiotherapy, Vol. 13, No. 2, 2017

ISSN: 0973-2020 (Print) $\quad \mathrm{I}_{2}$ OR Impact Factor = 5.23 UGC Approved [Journal No.7485] ISSN: 2454-6089 (online)

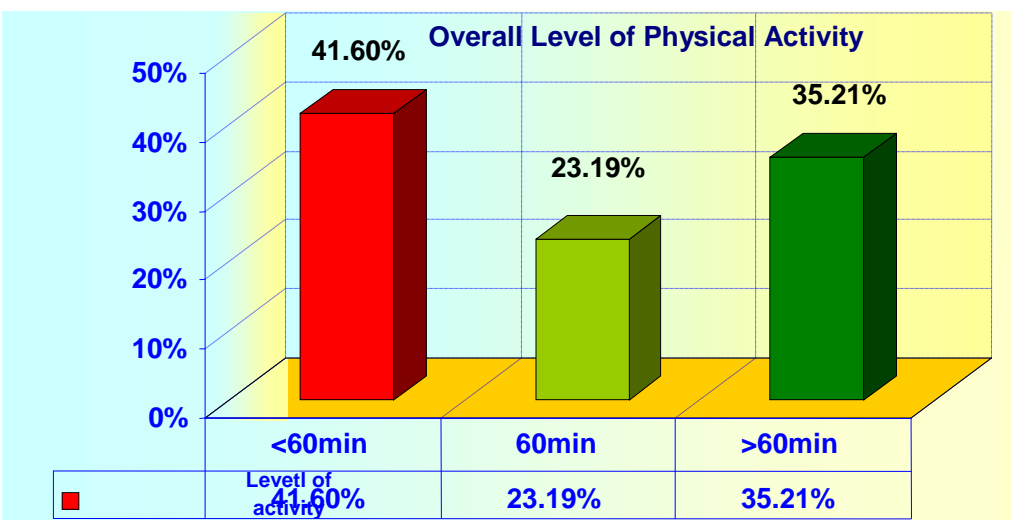

Figure 1. Level of physical activity per day in total population

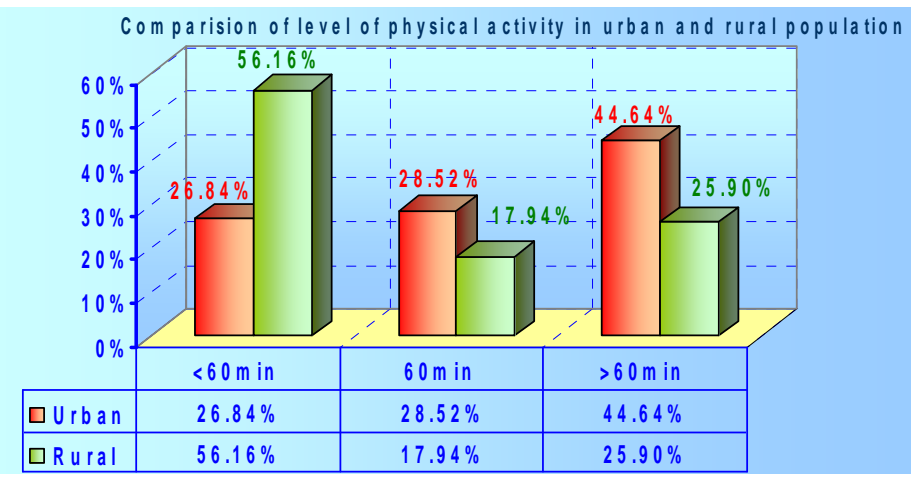

Figure 2. Comparison of level of physical activity per day in urban and rural population

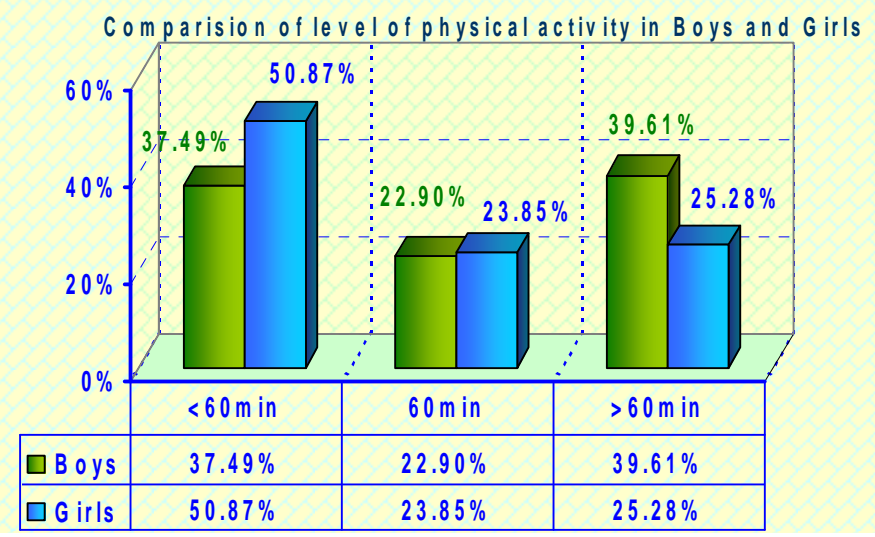

Figure 3. Comparison of level of physical activity per day amongst boys and girls 
Physical inactivity was found to be a risk factor in the incidence of diabetes mellitus, independent of body weight (Baan et al., 1999). Similarly, in the present study, obese diabetic children are more in physically inactive category. The Centers for Disease Control and Prevention recommend that schoolchildren should participate in at least 60 minutes of physical activity every day (Strong et al 2005). Among U.S. high school students, approximately one-third are not active enough to achieve the recommended levels of physical activity (Eisenmann, 2002). Cross-sectional data show that among children aged 9 to 13 years, 23\% do not engage in any physical activity during free time (Duke, 2003). In California, 30\% of adolescents aged 12-17 years do not achieve the recommended levels of physical activity and 7\% get no regular physical activity (Babey et al, 2005). Inadequate physical activity is associated with increased risks for chronic diseases like type 2 diabetes mellitus and cardiovascular disease and is also associated with increased risks for becoming overweight or obese (Strong et al, 2005 and Babey et al 2005). In addition to its association with health, physical activity is also related to academic performance. Research suggests that regular physical activity is associated with better academic performance (Dwyer et al, 2001, Shephard, 1997 and California Department of Education 2005). Among U.S. high school students, daily participation in physical education classes decreased from $42 \%$ during 1991 to $28 \%$ during 2003. Specific data is not available for younger students but on average, half of schools require physical education for students. In California, $15 \%$ of adolescents aged 12 to 17 years reported that their school does not require or offer physical education classes. These students are less likely to engage in regular physical activity than are students whose schools require physical education classes (Babey et al, 2005). Physical activity is known to reduce the risk of non-insulin dependent diabetes mellitus in younger. According to Williams et al. (1999), people with newly diagnosed diabetes were less physically active than their counter parts. In the study of Baan et al. (1999), a significant inverse association between physical activity and presence of diabetes was observed.There is evidence that physical activity increases peripheral sensitivity to insulin, especially in skeletal muscle and adipose tissue (Pescatello and Dipietro, 1993; Feskens et al., 1994). Besides, physical activity may improve weight reduction by increasing the energy expenditure associated with exercise because obesity is a major risk factor for developing diabetes (Horton, 1988 \& 1991). These findings, therefore, serves to strengthen the grounds for encouraging physical activity and exercise. A major characteristic of type- 2 diabetes is insulin resistance at the level of target tissues - possibly a post receptor defect (Taylor et al., 1984). A sedentary type of life could be one of the numbers of factors causing insulin resistance in an individual with genetic susceptibility to diabetes. Physical exercise is recommended as a part of therapy for type-2 diabetes because of increased insulin sensitivity during the exercise (Bjorntorp, 1982). Hence the main finding of the present study is repeated encouragement to increase physical activity and to do exercise to prevent the diabetes and its complications. Though the children were well informed about the good effects of physical activity but studies found that they were not engaged in daily physical activity. Only $30 \%$ of the overweight and obese children were engaged in at least 60 minutes of daily physical activity, which is suggestive of the sedentary lifestyle of the younger generation. The recent trend is that the school children concentrate more on academics and less in sports and physical activities. Leisure hours are spent in watching TV or playing computer/ video games, thus explaining the sedentary lifestyle of today's school children (Anthony et al 2000). Exercise is associated with improvement in short- and long-term metabolic control (Bloomgarden ,1999) and physical activity 
improves insulin sensitivity. Physical education classes may be helpful for children who are overweight. Monitoring changes in a child's environment may also play a role in the youth's physical activity behaviors today as compared to the past few decades (Ebbeling and Pawlak, 2002). Some environmental factors that may affect physical activity include the expense of the participation in some physical activities/ sports, the parents' lack of time to facilitate the child's active interests, and concerns about neighborhood and playground safety. As well, more and more schools are cutting physical education programs in the schools and the offered physical education programs are not providing requisite physical activity.

Table 2. Barriers to physical activity in total population

\begin{tabular}{|c|c|c|c|c|c|c|c|c|c|c|c|c|}
\hline \multirow[t]{2}{*}{$\begin{array}{l}\text { Grou } \\
\text { p/ } \\
\text { Sub } \\
\text { Grou } \\
\text { p }\end{array}$} & $\begin{array}{l}\text { No } \\
\text { Groun } \\
\text { d }\end{array}$ & & $\begin{array}{l}\text { Traff } \\
\text { ic }\end{array}$ & & $\begin{array}{l}\text { Hom } \\
\text { e } \\
\text { Wor } \\
\text { k }\end{array}$ & & $\begin{array}{l}\text { Stud } \\
\mathbf{y} \\
\text { Stre }\end{array}$ & & \multicolumn{2}{|l|}{$\begin{array}{l}\text { Paren } \\
\text { ts }\end{array}$} & \multicolumn{2}{|l|}{$\begin{array}{l}\text { Othe } \\
\mathbf{r}\end{array}$} \\
\hline & $\mathbf{N}$ & $\%$ & $\mathbf{N}$ & $\%$ & $\mathbf{N}$ & $\%$ & $\mathbf{N}$ & $\%$ & $\mathbf{N}$ & $\%$ & $\mathbf{N}$ & $\%$ \\
\hline $\begin{array}{l}\text { All } \\
\text { Data }\end{array}$ & 292 & $\begin{array}{l}14.2 \\
6\end{array}$ & 157 & $\begin{array}{l}7.6 \\
7\end{array}$ & 420 & $\begin{array}{l}20.5 \\
1\end{array}$ & 458 & $\begin{array}{l}22.3 \\
6\end{array}$ & 362 & $\begin{array}{l}17.6 \\
8\end{array}$ & 359 & $\begin{array}{l}17.5 \\
3\end{array}$ \\
\hline \multicolumn{13}{|l|}{ Area } \\
\hline Urban & 108 & $\begin{array}{l}10.6 \\
2\end{array}$ & 62 & $\begin{array}{l}6.1 \\
0\end{array}$ & 255 & $\begin{array}{l}25.0 \\
7\end{array}$ & 246 & $\begin{array}{l}24.1 \\
9\end{array}$ & 84 & 8.26 & 262 & $\begin{array}{l}25.7 \\
6\end{array}$ \\
\hline Rural & 184 & $\begin{array}{l}17.8 \\
5\end{array}$ & 95 & $\begin{array}{l}9.2 \\
1\end{array}$ & 165 & $\begin{array}{l}16.0 \\
0\end{array}$ & 212 & $\begin{array}{l}20.5 \\
6\end{array}$ & 278 & $\begin{array}{l}26.9 \\
6 \\
\end{array}$ & 97 & 9.41 \\
\hline & & & & & & & & & & $\mathrm{Chi}^{\wedge} \mathbf{2}=$ & $28.24 *$ & $\begin{array}{l}\text { (df:5) } \\
=0.32\end{array}$ \\
\hline
\end{tabular}

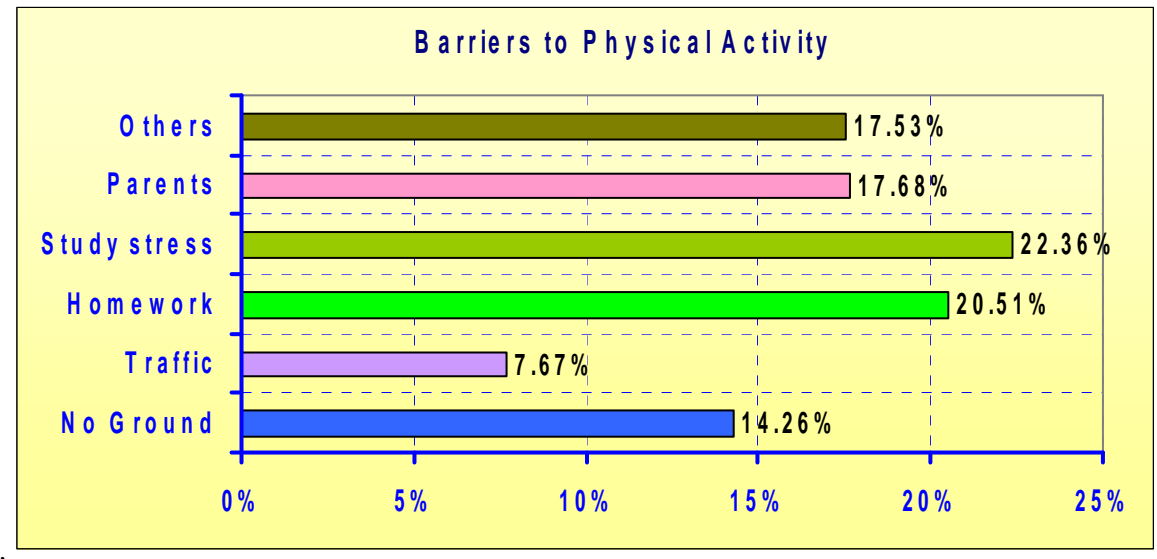

Figure 4. Barriers to Physical Activity 
Journal of Exercise Science \& Physiotherapy, Vol. 13, No. 2, 2017

ISSN: $0973-2020$ (Print) I I OR Impact Factor = 5.23 UGC Approved [Journal No.7485] ISSN: 2454-6089 (online)

Table 3. Mode of transport used for school in total population

\begin{tabular}{|c|c|c|c|c|c|c|c|c|c|c|c|c|c|c|c|c|}
\hline \multirow{2}{*}{$\begin{array}{l}\text { Group } \\
\text { / } \\
\text { Sub } \\
\text { Group }\end{array}$} & \multicolumn{2}{|c|}{ Bus } & \multicolumn{2}{|c|}{ Rickshaw } & \multicolumn{2}{|c|}{ Auto } & \multicolumn{2}{|c|}{ Bicycle } & \multicolumn{2}{|c|}{ Walk } & \multicolumn{2}{|c|}{ Car } & \multicolumn{2}{|c|}{$\begin{array}{l}\text { Bike/ } \\
\text { Scoot }\end{array}$} & \multicolumn{2}{|c|}{$\begin{array}{l}\text { M. } \\
\text { Cycle }\end{array}$} \\
\hline & $\mathbf{N}$ & $\%$ & $\mathbf{N}$ & $\%$ & $\mathbf{N}$ & $\%$ & $\mathbf{N}$ & $\%$ & $\mathbf{N}$ & $\%$ & $\mathbf{N}$ & $\%$ & $\mathbf{N}$ & $\%$ & $\mathbf{N}$ & $\%$ \\
\hline $\begin{array}{l}\text { All } \\
\text { Data }\end{array}$ & \begin{tabular}{|l|l|}
33 \\
8 \\
\end{tabular} & $\begin{array}{l}16.5 \\
0 \\
\end{array}$ & $\begin{array}{l}17 \\
4 \\
\end{array}$ & 8.50 & $\begin{array}{l}4 \\
4 \\
\end{array}$ & $\begin{array}{l}2.1 \\
5 \\
\end{array}$ & \begin{tabular}{|l|l}
31 \\
6
\end{tabular} & $\begin{array}{l}15.4 \\
3\end{array}$ & $\begin{array}{l}98 \\
5 \\
\end{array}$ & $\begin{array}{l}48.1 \\
0\end{array}$ & $\begin{array}{l}14 \\
8 \\
\end{array}$ & 7.23 & $\begin{array}{l}3 \\
7 \\
\end{array}$ & $\begin{array}{l}1.8 \\
1 \\
\end{array}$ & 6 & $\begin{array}{l}0.2 \\
9 \\
\end{array}$ \\
\hline Area & & & & & & & & & & & & & & & & \\
\hline Urban & $\begin{array}{l}27 \\
5\end{array}$ & $\begin{array}{l}27.0 \\
4\end{array}$ & $\begin{array}{l}11 \\
3\end{array}$ & $\begin{array}{l}11.1 \\
1\end{array}$ & $\begin{array}{l}3 \\
1\end{array}$ & $\begin{array}{l}3.0 \\
5\end{array}$ & $\begin{array}{l}24 \\
8\end{array}$ & $\begin{array}{l}24.3 \\
9\end{array}$ & $\begin{array}{l}19 \\
6\end{array}$ & $\begin{array}{l}19.2 \\
7\end{array}$ & $\begin{array}{l}12 \\
0\end{array}$ & $\begin{array}{l}11.8 \\
0\end{array}$ & $\begin{array}{l}2 \\
9\end{array}$ & $\begin{array}{l}2.8 \\
5\end{array}$ & 5 & $\begin{array}{l}0.4 \\
9\end{array}$ \\
\hline Rural & 63 & 6.11 & 61 & 5.92 & $\begin{array}{l}1 \\
3\end{array}$ & $\begin{array}{l}1.2 \\
6\end{array}$ & 68 & 6.60 & $\begin{array}{l}78 \\
9\end{array}$ & $\begin{array}{l}76.5 \\
3\end{array}$ & 28 & 2.72 & 8 & $\begin{array}{l}0.7 \\
8\end{array}$ & 1 & $\begin{array}{l}0.1 \\
0\end{array}$ \\
\hline
\end{tabular}

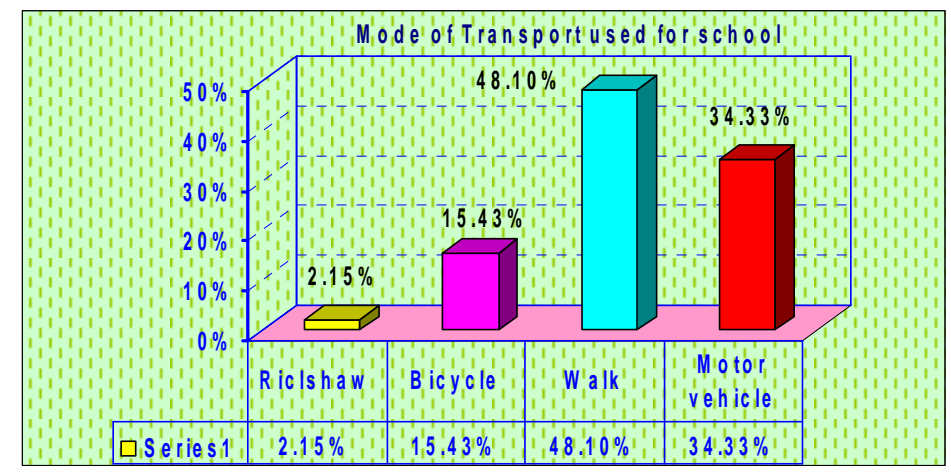

Figure 5. Modes of Transport used in schools

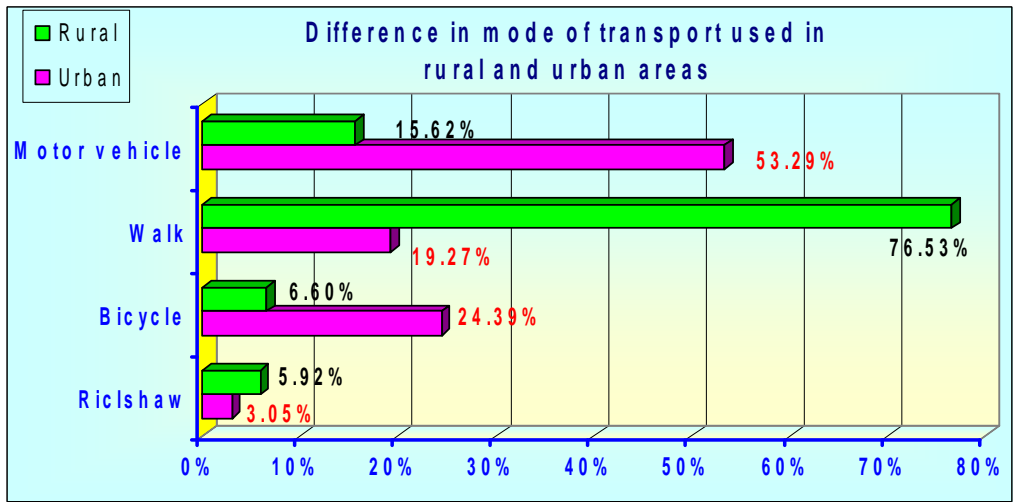

Figure 6. Modes of Transport used in schools of rural and urban areas 
In this study, barrier to physical activity is found to be study stress which is more in urban area as compared to rural areas Another important factor is the parental pressure on children to perform well in academics at the cost of sports and other physical activities. Lack of play fields in schools and open spaces around homes, has further aggravated the problem. Table 3 shows the mode of transport to school, in urban areas most of the students were traveling by motor vehicles $(53.29 \%)$ and in rural areas by walking (76.53\%).11.7\% obese and $13.6 \%$ overweight subjects were not involved in playing activities and this finding was statistically significant. The prevalence of overweight and obesity among subjects using bus as mode of transport was found as $20.4 \%$ and $8.7 \%$ compared to subjects using cycle as a mode of transport in which it was $7.2 \%$ and $4.4 \%$, respectively. Using bus as the mode of transport, not playing outdoor games, and sibling count more than two are independent predictors for being overweight and obesity. Goyal et al. observed that going to school by bus/auto was associated with 2.14 times risk of developing obesity (Goyal et al, 2011) while Joshi et al. reported that the mode of conveyance to school differed significantly among normal, overweight, and obese subjects (Joshi et al,2012). Guedes et al. on multivariate analysis found 1.5 times risk of developing obesity with car being used as a mode of transport (Guedes et al,2011). Similarly, increases in active modes of transport to and from school (walking, cycling, and public transport) would require policy changes at the school and local government levels, as well as support from parents and the community. In some communities a variety of such programs have been implemented e.g. road crossings, 'walking bus', and designated safe walking and cycling routes (Swinburn and Egger, 2002).

Conclusion: Schools influence the food and physical activity environments of children Schoolbased preventive programs for lifestyle and behavioral modification will play important role to combat this problem. The significance of this study, thus, lies in the fact that children and adolescents were unaware of their disease status and have a sedentary life style. Obesity can be prevented may be achieved through a variety of interventions like to inroduce compulsory games period in schools, physical education classes, better walking arrangement like footpaths, the cycling roads, parks and recreation centers etc. These strategies can be initiated at home and in schools to form an appropriate built environment. However, further research is needed to examine the most effective strategies of intervention, prevention, and treatment of obesity.

\section{Acknowledgement}

The author is highly thankful to UGC for providing grant for undertaking the research award.

\section{References}

Africa JA, Newton KP, Schwimmer JB. 2016. Lifestyle interventions including nutrition, exercise, and supplements for nonalcoholic fatty liver disease in children. Dig Dis Sci. ;61(5):1375-1386

Anderson PM, Butcher KE. Childhood obesity: Trends and potential causes. Future Child.2006;16:19-45.

Anthony JG, Stewart BH, Joel G, et al.2000. Overweight among children and adolescents in a native Canadian community: prevalence and associated factors. Am J Clin Nutr; 71: 693-700.

Baan, C.A., Stolk, R.P., Grobbee, D.E., Witteman, J.C.M. and Feskens, E.J.M. 1999. Physical activity in elderly subjects with impaired glucose tolerance and newly diagnosed diabetes mellitus. Am. J. Epidemiol,149: 219-227.

Babey SH, Diamant AL, Brown ER, Hastert T. 2005. California adolescents increasingly inactive. Los Angeles: University of California, Los Angeles Center for Health Policy Research.

Bacha F, Gidding SS. 2016. Cardiac abnormalities in youth with obesity and type 2 diabetes. Curr Diab Rep.;16(7):62

Bass R, Eneli I. Severe .2015. Childhood obesity: an under-recognized and growing health problem. Postgrad Med J.;91(1081):639-45. doi: 10.1136/postgradmedj-2014-133033

Beck AR. Psychosocial aspects of obesity. NASN Sch Nurse. 2016;31(1):23-27.

Bjorntorp, P. 1982. Effects of physical training on diabetes mellitus, type-II. In: Bostrom, H., Ljungstedt, N. (eds.). Recent trends in diabetes research. 


\section{Journal of Exercise Science \& Physiotherapy, Vol. 13, No. 2, 2017 \\ ISSN: $0973-2020$ (Print) $\quad \mathrm{I}_{2}$ OR Impact Factor = 5.23 UGC Approved [Journal No.7485] ISSN: 2454-6089 (online)}

Bloomgarden ZT. 1999. American Diabetes Association Annual Meeting, 1998: insulin resistance, exercise, and obesity. Diabetes Care; $22: 517-522$.

California Department of Education. 2005. A study of the relationship between physical fitnessand academic achievement in California using 2004 test results.. Sacramento.

Center for Disease Control (CDC). 2000.Body mass Index: BMI for children and teens..apps.nccd.cdc.gov/dnp abmi.

Centers for Disease Control and Prevention. 2003. National Diabetes Fact Sheet: General Information and National Estimates on Diabetes in the United States,. Rev. ed. Atlanta, Ga., U.S. Department of Health and Human Services, Centers for Disease Control and Prevention, 2004

Duke J, Huhman M, Heitzler C. 2003. Physical activity levels among children aged 9-13 years-United States, 2002..MMWR. 52:785-8.

Dwyer T, Sallis JF, Blizzard L, Lazarus R, Dean K. 2001. Relation of academic performance to physical activity and fitness in children. Ped Exer Sci.; 13:225-37.

Ebbeling C \& Pawlak DB2002. Childhood obesity: public health crisis, common sense cure. Lancet; 360: 473-482

Eisenmann JC, Bartee RT, Wang MQ. 2002. Physical activity, TV viewing and weight in U.S.youth: 1999 youth risk behavior survey. Obes Res. 10:379- 85.

Feskens, E.J.M., Loeber, J.G. and Kromhout, D. 1994. Diet and Physical activity as determinants of hyperinsulinaemia : The Zutphan Elderly study. Am. J. Epidemiol., 140: $350-360$.

Goyal JP, Kumar N, Parmar I, Shah VB, Patel B. 2011. Determinants of overweight and obesity in affluent adolescent in Surat City, South Gujarat region, India. Indian J Community Med:36:296-300.

Guedes DP, Rocha GD, Silva AJ, Carvalhal IM, Coelho EM. 2011. Effects of social and environmental determinants on overweight and obesity among Brazilian schoolchildren from a developing region. Rev Panam Salud Publica. ;30:295-302.

Guo SS, Huang C, Maynard LM, Demerath E, Towne B, Chumlea WC, et al. 2000. Body mass index during childhood, adolescence and young adulthood in relation to adult overweight and adiposity: The Fels longitudinal study. Int $J \quad$ Obes Relat Metab Disord ;24:1628-35.

Horton, E.S. 1988. Role and management of exercise in diabetes mellitus. Diabtes Care; 11: 210-211.

Horton, E.S. 1991. Exercise and decreased risk of NIDDM. N. Eng. J. Med; 325: 196-197.

Joshi M, Gumashta R, Kasturwar NB, Deshpande A. 2012. Avoid junk food and start cycling to school: An easy way to manage adolescent obesity. Int J Pharm Biol Sci.;4:21-7.

Kapil U, Bhadoria AS. 2014. Television viewing and overweight and obesity amongst children. [Last accessed on 2014 Jul 11];Biomed J. 37:337-8.

Martorell R, KettelKhan L, Hughes ML, Grummer-Strawn LM. 2000. Overweight and obesity in preschool children from developing countries. Int J Obes Relat Metab Disord:;4:959-67.

Mohanan S, Tapp H, McWilliams A, Dulin M. 2014. Obesity and asthma: pathophysiology and implications for diagnosis and management in primary care. Exp Biol Med (Maywood);239(11):1531-40.

Pescatello, L.S. and Di Pietro, L. 1993. Physical activity in older adults, An overview of helath beneifts. Sports Med.;15:353-364

Pollock NK. 2015. Childhood obesity, bone development, and cardiometabolic risk factors. Mol Cell Endocrinol.;410:52-63. doi: 10.1016/j.mce.2015.03.016.

Popkin BM. 2016. The nutrition transition and obesity in the developing world. J Nutr Bacha F, Gidding SS. Cardiac abnormalities in youth with obesity and type 2 diabetes. Curr Diab Rep.; 16(7):62. doi: 10.1007/s11892-016- 0750-6.

Pouliot MC, Després JP, Lemieux S, Moorjani S, Bouchard C, Tremblay A, et al. 1994. Waist circumference and abdominal sagittal diameter: Best simple anthropometric indexes of abdominal visceral adipose tissue accumulation and related cardiovascular risk in men and women. Am J Cardiol. ;73:460-8.

Shephard RJ. 1997. Curricular physical activity and academic performance. Ped Exer Sci.;9:113-26.

Strong WB, Malina RM, Blimkie CJ et al. 2005. Evidence based physical activity for school-age youth. Pediatrics. 146:732-7. 
Swinburn B, Egger G. 2002. Preventive strategies against weight gain and obesity. Obes Rev., 3: 289-301.

Taylor, R., Ram, P., Zimmet, P., Rapper, L.R. and Ringrose, H. 1984. Physical activity and prevalence of diabetes in Melanesian and Indian men in Fiji. Diabetologia; 27: 578 582.

The Expert Committee on the Diagnosis and Classification of Diabetes Mellitus' 2003 from the American Diabetes Association, Alexandria, Virginia Diabetes Care; 26:S5-S20.

Williams, E.M. Desmond, Warehem J. Nicholas, COX, D. Brain Byrne Christopher, Hales Nicholas, C. Day, E. Nicholas. 1999. Frequent Salad vegetable consumption is associated with reduction in the risk of diabetes mellitus. J. Clin. Epidemiol; 52 (4): 329-335.

World Health Organization Study Group on Diabetes Mellitus Technical Report Series, 727, WHO Geneva, 1985.

World Health Organization. 2014. Controlling the global obesity pandemic (document on the internet) [Last accessed on, Jul 17,2014]. Available from:http://www.who.int/nutrition/topics/obesity/en

World Health Organization. 1998. Obesity: preventing and managing the global epidemic. Report of a WHO consultation on Obesity, Geneva, 3-5, June 1997. World Health Organization: Geneva;.

Conflict of Interest: None Declared 